\title{
An Empirical Investigation on the Impact of Crowd Participation on the Degree of Project Success: The Perspective of Crowd Capital
}

\author{
Chunxiao Yin \\ Southwest University, China \\ yincx@swu.edu.cn
}

Ivy Libo Liu

Swinburne University of

Technology, Australia

liboliu@swin.edu.au

\author{
Kai H. Lim \\ City University of Hong Kong, \\ Hong Kong, China \\ iskl@cityu.edu.hk
}

\author{
Kristijan Mirkovski \\ Victoria University of Wellington, New Zealand \\ kmirkovsk2@gmail.com
}

\begin{abstract}
Fundraisers expect to raise as much funds as possible even after they have reached initial threshold of funding goal. This study focuses on the degree of project success defined as the total amount of funds a project can obtain after it is already successful (reached the initial threshold offunding goal). Drawing upon the theory of crowd capital, this study aims to explore the effect of the crowds-represented as crowd participation - on the degree of project success. Three types of crowd participation are identified, namely funds pledge, popularity creation, and on-site communication. We postulate that funds pledge will have an inverse $U$-shaped relationship with the degree of project success; while the other two factors will positively influence the degree of project success. Our empirical data from a reward-based crowdfunding platform supported our predictions for funds pledge and on-site communication. Future research and implications are discussed.
\end{abstract}

\section{Introduction}

Successful fundraising is critical for the success of new business ventures. While it is quite difficult for small business projects to access funds through traditional fundraising channels (e.g., venture capital, angel investment, donations etc.), the emergence of various crowdfunding platforms significantly simplified and facilitated the fundraising process. All fundraising campaigns launched on crowdfunding platforms have a goal of successfully raising funds. Prior crowdfunding literature has studied the antecedents of project success; that is, how a project could achieve its set goal $[3,19$, $32,34,35]$. However, these studies were mainly from the perspective of fundraisers by examining factors such as project quality, social capital of fundraisers, and project design strategies.

In fact, crowdfunding is not a single-side market only accommodating fundraisers; it is a two-sided market that interlinks capital-seeking agents (i.e., fundraisers) and an IT-mediated crowd of capital-giving agents (i.e., backers or funders) [13]. Through it, fundraisers can seek resources (i.e., funds in crowdfunding platforms) from an IT-mediated crowd, which is asserted as a new emergent capital named "crowd capital" in the theory of crowd capital [27]. The theory was developed to explore how organizations obtain resources, such as knowledge and money, from IT-mediated crowds, and is also appropriate for explicating the underlying logic of fundraising in the crowdfunding context. According to this theory, the generation of crowd capital (i.e., successfully raising funds on crowdfunding platforms) relies on both the disperse resources of the crowds - the indispensable antecedent condition, and the crowd capability of organizations (including structure, content, and process)-fundraisers in the current context [27]. Therefore, it is equally important to take the role of the crowds into account as well as the crowd capability (i.e., organization's capability to engage the IT-mediated crowds) of fundraisers. Since the crowd capability of fundraisers has been well-studied in the past $[3,19,32$, $34,35]$, we choose to focus on the effect of the crowds on generating crowd capital, i.e., crowdfunding project success in the current context.

For project fundraisers, they acquire disperse resources (i.e., money) from different crowds, which is manifested on the crowdfunding platforms through the participation or contribution behaviors of different crowds [6]. On a crowdfunding platform, there are three ways for crowds to participate: (1) funds pledge, (2) popularity creation (i.e., clicking like), and (3) on-site 
communication (i.e., interaction between the crowds and fundraisers). Funds pledge is the fundamental way of participation with which the crowds can provide funds to support their preferred projects. In addition, crowdfunding platforms also integrate specific on-site social features [9], such as popularity indices (i.e., allowing participators to "like" certain project) and communication functions (i.e., allowing participants to communicate with fundraisers by giving comments and receiving responses). This study aims to explore the effects of these three types of crowd participation on the crowdfunding project success.

Unlike prior studies which concentrate on the likelihood to succeed, the current study focuses on the degree of project success that is defined as the total amount of funds a project can obtain after it is already successful (reached the initial funding goal). All of the crowdfunding projects not only expect the probability of achieving its initial funding goal, but also largely exceeding it. Exceeding the initial funding goal helps projects to smoothly start up the new ventures. For example, even though the original funding target was set at $\$ 15,000$, TikTok, a gadget that converts Apple iPod Nano into a watch, turned out to be extremely attractive for investors and succeeded to raise almost 1 million dollars. Its further business went very well with the large amount of funds raised from Kickstarter. Moreover, overwhelmingly successful projects, called 'blockbuster projects', can also affect other projects within the same category in the amount of funds because of the network effects, as indicated in the study of Liu, Yang, Wang and Hahn [18]. With this in mind, our study stresses on the degree of project success by constructing it as the crowd capital, and explore the effects of the crowds represented as crowd participation. Accordingly, the research question of this study is specified as: What are the effects of crowd participation on the degree of project success on crowdfunding platforms?

The reminder of the study is organized as follows. An introduction to crowdfunding and a literature review of crowdfunding project success are presented next, followed by the theoretical background about the theory of crowd capital. Hypotheses development is presented in following section. Then the research methods and results are described. Finally, Implications and future research are discussed.

\section{Theoretical Background}

\subsection{Crowdfunding}

\footnotetext{
${ }^{1} \mathrm{http}: / /$ crowdexpert.com/crowdfunding-industry-statistics
}

Crowdfunding has been defined in many ways. The core of all these definitions is to raise funds through collective individuals usually via the Internet. For example, Schwienbacher and Larralde [28] defined crowdfunding as "the financing of a project or a venture by a group of individuals instead of professional parties" (p.370). Burkett [5] regarded crowdfunding as "a process where entrepreneurs, artists, and nonprofits raise money for their projects, businesses, or organizations by gaining the support of many people on the internet who collectively contribute money to projects to which they feel some affinity" (p.66).

Crowdfunding has become a significant and efficient way for many businesses to raise funds. The volume of funds raised from crowdfunding platforms has experienced a steep increase in the past years. According to Massolution ${ }^{1}$ Crowdfunding Report 2015, the global crowdfunding industry raised $\$ 34.5$ billion in 2015 and is predicted to surpass venture capital by 2016. Kickstarter announced in the February 2016 that the total number of successful fundraising projects on Kickstarter surpassed 100 thousands ${ }^{2}$. It was also mentioned that fundraising cycle was significantly faster and shorter than before; that is, today, only 3 days are needed to successfully fund 100 projects, which back to 2009 was 121 days.

There are four types of crowdfunding platforms: donation-based, reward-based, equity-based, and lending-based [8]. Donation-based crowdfunding platforms, such as Crowdrise, allow the crowds to pledge funds on projects but without existential reward. The typical campaigns in such platforms are charity projects. The crowds fund projects in the reward-based crowdfunding platforms, such as Kickstarter, IndieGoGo, and Zhongchou.cn, for tangible but nonfinancial benefits. The equity-based and lending-based crowdfunding platforms, such as SellaBand, Wefunder, and AngelCrunch, involve in financial returns or profit sharing $[1,31,33]$.

Crowdfunding platforms also differ in their funding models, namely All-or-Nothing funding model (such as Kickstarter) or Keep-What-You-Raise funding model (such as IndieGoGO) [10]. Within an All-or-Northing model, a fundraiser sets a funding goal in advance, and he/she receives no funds if this goal cannot be reached. While a fundraiser can receive the pledged funds no matter the funding goal is achieved or not when raising funds in the Keep-What-You-Raise funding model.

This study is interested in reward-based crowdfunding platforms involving in the All-orNothing model. This type of crowdfunding platform has the largest number of users and is the fastest growing

\footnotetext{
2 https://www.kickstarter.com/blog/kickstarters -impact-on-the-
} creative-economy?__prclt=MEfr3abs 
one on a global scale. In addition, reaching the funding goal is the basic criterion such that achieving high degree of success is significantly important on this type of crowdfunding platforms.

\subsection{Crowdfunding Project Success}

Prior research has started to pay attention to the determinants of project success on crowdfunding platforms. Generally, there are four primary research direction related to the project success on crowdfunding platforms (see Table 1). First, project quality is considered as a key predictor to project success, including quality of project description (i.e., media usage, spelling error, etc.), intensity of updates, duration of projects, etc. [3,21].

\begin{tabular}{|l|l|l|}
\hline \multicolumn{3}{|c|}{ Table 1. A Literature Review of Crowdfunding } \\
Project Success \\
\hline \multicolumn{2}{|c|}{ Research Perspectives } & \multicolumn{1}{c|}{ References } \\
\hline \multirow{4}{*}{$\begin{array}{l}\text { Capital } \\
\text { seeking } \\
\text { perspective }\end{array}$} & Project quality & {$[3,21]$} \\
\cline { 2 - 3 } & Social capital & {$[11,21,36]$} \\
\cline { 2 - 3 } & $\begin{array}{l}\text { Social media } \\
\text { usage }\end{array}$ & {$[3,20]$} \\
\cline { 2 - 3 } & $\begin{array}{l}\text { Project design } \\
\text { strategies }\end{array}$ & {$[19,32,34]$} \\
\hline
\end{tabular}

Second, some studies explored the project success by focusing on the perspective of social capital associated with the fundraisers $[11,21,35]$. Specifically, Giudici, Guerini and Lamastra [11] distinguished between individual and territorial social capital, and concluded that the individual social capital positively affected the crowdfunding project success, while the geo-localized capital had negative influence on the project success. Mollick [21] noted that social network size played a key role in determining the crowdfunding success, which was explained through the family and friends effects. Zheng, $\mathrm{Li}, \mathrm{Wu}$ and $\mathrm{Xu}$ [35] identified three dimensions of social capital based on the social capital theory, including social network ties, obligations to fund others, and the shared meaning of project between the entrepreneurs and other sponsors.

Third, the effects of social media, which are embedded in crowdfunding platforms as off-site communication channels, are also examined in relation to their impact on the project success $[3,20]$. Beier and Wagner [3] indicated that usage of homepage could significantly affect project success. Moisseyev [20] proposed that the number of social media followers predicted the project success.

Forth, project design strategies for fundraisers may also predict project success. For instance, the effect of project reward structure on project outcomes was examined, and it was found that the reward levels with popular options till date were perceived to be more favorable [34]. Another study indicated that a project with higher maximum backing price and less reward tiers in the reward schemes could raise more money [32]. The design of video advertisement content was also found to influence the pledge volume [19].

These studies offer valuable insights in understanding project success. However, there are still two limitations, which present significant research opportunities. First, crowdfunding is a two-sided market, which connects both capital-seeking agents (i.e., fundraisers) and capital-giving agents (i.e., the crowds) [13]. The existing studies on crowdfunding project success is mostly from the perspective of fundraisers. The studies of project success from the perspective of the crowds, however, are still rare. As we will elaborate later, both the fundraisers and the crowds are equally important in the process of fundraising. Second, most of previous studies consider success as a binary concept: success vs. not success. However, the degree of project success, which is underexplored, is also critical because fundraisers expect to raise more funds even after successfully meeting their initial funding goals, in order to better assist new ventures. Furthermore, the projects with extremely high degree of success (i.e., blockbuster projects) can also increase the amount of funds raised by other projects within the same category [18]. This is because the blockbuster project can attract more potential funders to the platforms and later to the projects within the same category.

Our study intends to fill these research gaps by exploring the degree of project success from the perspective of capital-giving agent-the crowds. We draw upon the theory of crowd capital to build the relationships between the crowds and the degree of project success.

\subsection{Crowd Capital}

The theory of crowd capital is recently developed by John Prpić and his colleagues to describe the process of how IT-mediated crowds generate resources or values for organizations [22, 24, 25, 27]. The crowd capital is firstly conceptualized as "a heterogeneous organizational knowledge resource, generated by the organization' Crowd Capability: an organizational level capability that is defined by the structure, content, and process of an organizations engagement with the dispersed knowledge of individuals-the Crowd" [22, p2]. This definition considers crowd capital as knowledge resources because the theory of crowd capital was originally developed in the context of knowledge sourcing. Later, it was extended to refer to a broad range of organizational resources, including knowledge, funds, opinions, etc., generated from IT-mediated crowds [22, 
27]. Thus, it can capture research contexts that are closely associated with the engagement of an ITmediated crowd, such as Crowdsourcing, Crowdfunding, and Open innovation platforms.

Although crowd capital is an organizational resource, it is different from other types of organizational resources, such as the well-known social capital, in the sense that it does not require the network of relationships hold by organizations and it is based on dispersed and unique resources possessed by ITmediated crowds [22]. Actually, it is the key benefit that organizations seek from IT-mediated crowd engagement [25], and is the outcome or potential outcome of engaging IT-mediated crowds $[22,26]$. In the context of crowdfunding, the funds successfully raised from the crowds are the outcome of the crowdengagement for fundraisers. Therefore, the theory of crowd capital is also applicable to explain the process of fundraising, and the degree of project success could be considered as the key crowd capital in this context.

The theory of crowd capital is a process theory; however, it proposes two critical conditions for crowd capital generation-crowd capability of the organization and dispersed resources of the crowd. Crowd capability refers to an organization's capability to engage the IT-mediated crowds, including three dimensions: structure-what information technology will be used, content-what resources are sought, and process-how to obtain desired sources [22, 23]. The antecedents studied from capital-seeking agent perspective in prior literature can be categorized into crowd capability of fundraisers. For example, project design strategies can be considered as the process dimension of crowd capability because fundraisers acquire funds through different ways of design.

In addition to crowd capability, another indispensable antecedent condition is the 'dispersed resource' embedded in the crowd [22, 27]. The crowds possess dispersed and unique resources, and are expected to aggregate their resources to organizations. On the crowdfunding platforms, the crowds contribute their resources (e.g., funds) through their participation behaviors. Therefore, crowd participation is significant for crowd capital generation of fundraisers. The objective of this study is to explore the role of crowd participation on the degree of project success.

As stated, there are three ways a crowd can participate in the crowdfunding platforms, and show interests in and devote resources to projects, namely funds pledge, popularity creation (i.e., clicking like), and on-site communication (i.e., giving comments and receiving responses). With funds pledge, the crowds support crowdfunding projects substantially and help projects to be successful by achieving funding goals and by getting more funds after the projects have successful reached the initial funding goals. Besides, the crowds can also participate through the usage of on-site social functions, such as clicking "like" button and interacting with fundraisers. These on-site social functions represent the popularity of projects and help the crowds communicate with fundraisers. Our study focuses on these three specific ways, and intends to investigate the effects of crowd participation on the degree of project success. The research framework is depicted in Figure 1.

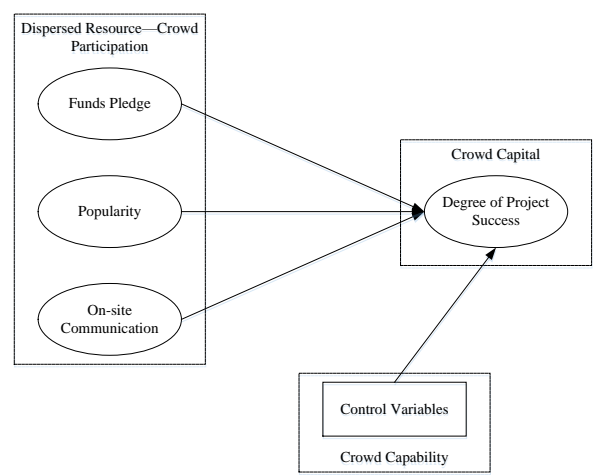

Figure 1. Research Framework

\section{Hypotheses Development}

\subsection{Funds Pledge}

Funds pledge is the most fundamental behavior of the crowds on the crowdfunding platforms. This behavior is studied in prior literature to explore how and when the crowds pledge. The studies of equity-based and lending-based crowdfunding platforms find that the crowd will manifest a herding behavior when they decide to pledge funds on a project [33]. Given that financial return is the major expectation in these platforms, following others is a rational way for individuals to look for high quality projects. This implies that a project with high degree of success will attract more funders.

However, it is observed in the study of donationbased crowdfunding platforms that a crowding-out effect may occur when individuals perceive others' contributions on a project as sufficient [2]. That is, individuals would decrease their contributions when others have already contributed more to a project and turn to other projects with less success [6]. This is because the crowds participant in donation-based crowdfunding platforms for the purpose of helping others without tangible or financial rewards [6, 29]. Accordingly, it implies that a project with a high degree of success may not be necessary the project attracting the largest amount of funders.

The focus of this study is the reward-based crowdfunding platforms, on which funders do receive 
tangible rewards but not as sensitive as financial rewards. Hence, the funders' pledge behavior on these platforms must be different from that of equity-based or donation-based crowdfunding platforms. Their goals in participating reward-based crowdfunding platforms include both seeking rewards and helping project initiators [10]. Previous studies have obtained mixed findings about the funders' pledge behaviors on rewardbased crowdfunding platforms. Some studies indicated that funds pledge behavior occurs when the crowds find the project already to have high degree of success $[17$, 30]; while others found the opposite results that the crowds will pledge the projects with less success presumably out of goodwill or benevolence to help others [16]. With it in mind, we postulate that the effect of funds pledge on the degree of project success should be mixed.

Specifically, at the early stage, a project that has already obtained the set funding goal will continuously attract funders, because the initial success signals the good quality of the project and indicates the high probability that the project will keep its promises. Thus, it will attract more funders to pledge funds. Later, when a project has received funds largely exceeding its set funding goal and even become a blockbuster project, the crowds may turn to other similar projects with less success. Since the crowds are able to check the status of the project from the very beginning to its completion, they would like to choose those projects that are either approaching or have just reached their funding goals. This can help the project initiators to successfully raise money on one hand, and can lower the probability of losses to crowds on the other hand because these projects either have higher probability of success or have already achieved success in reaching the initial funding goals. In a conclusion, we postulate that there exists a tipping point between the crowd participation in funds pledge and the degree of project success: they are positively related before the tipping point, while are negative related after the tipping point. Therefore, we hypothesize that:

H1: The crowd participation in funds pledge has an inverse U-shapedrelationship with the degree of project success.

\subsection{On-site Social Functions}

Prior studies have recognized the effects of off-site social communications on project success [3, 14]. In addition to the functions to share projects into off-site social network sites, crowdfunding platforms also provide some on-site social functions, such as popularity index (i.e., giving "likes") and on-site communication(i.e., providing comments and receiving responses). We separate these two functions according to the number of parties involved. Specifically, popularity creation only requires the effort of the crowds to click "like" button, while on-site communication required the effort of both parties - the crowds give comments and the fundraisers respond to the comments. In other words, on-site communication involves interactions between the crowds and the fundraisers, and popularity creation only involves one party - the crowds.

By participating on these on-site social functions, the crowds can also express their supports on the preferred projects. These types of supports are different from funds pledge in the sense, that they can either be not related to any types of rewards for the crowds or provide any substantial financial support for project initiators. Therefore, their effects on the degree of project success should also be studied separately from funds pledge.

3.2.1 Popularity Creation. Popularity refers to the concept of "widely liked" [4]. A person with high popularity is considered as been perceived as having high attractiveness and good achievement [37]. Similarly, the projects with high popularity are those which are perceived by the crowds as having high attractiveness. Crowdfunding platforms commonly display a project popularity index (i.e., the number of "likes" a project received), which indicates the number of the crowds who think that the focal project is attractive and have good quality. The crowds can click the "like" button to express their support for their preferred projects, which in turn create popularity indexes of the projects.

The popularity of a task predicts its success [15]. Therefore, we also expect that a project's popularity helps to promote the project. When a project is more popular, it can attract more attentions, has more potentials to receive substantial financial supports, and could receive more funds even after it achieves its original funding goal. Thus, we hypothesize that:

H2: The crowd participation in popularity creation is positively related to the degree of project success.

3.2.2 On-site Communication. Another on-site social function is the on-site communication, representing as giving comments to and receiving responses from fundraisers on crowdfunding platforms. It allows the crowds to interact with current and prospective project fundraisers. For instance, they can respond to project fundraisers by leaving comments or feedbacks, and the fundraisers can respond to the comments. This feature enhances the interaction between the crowds and the fundraisers. 
Previous studies in other contexts, such as new product development, indicated the motivating role of communication [7, 12]. Similarly, studies on crowdfunding shows that the frequency of communication between project fundraisers and funders positively relates to the volume of fund raised [32]. Thus, we also expect that the more the crowds involve in onsite communication, the higher the funds the project can raise even after it reaches its funding goal. Accordingly, we hypothesize that:

H3: The crowd participation in on-site communication is positively related to the degree of project success.

\section{Methodology}

\subsection{Data Collection}

We collected data from zhongchou.cn (http://www.zhongchou.cn/), one of the biggest rewardbased crowdfunding platform in China. Zhongchou.cn provides an online crowdfunding platform which enables companies to issue calls for funds over the internet and receive small investments from registered users in return. It is similar to Kickstarter, and is a typical reward-based, All-or-Nothing Crowdfunding model. Launched in 2013, Zhongchou.cn has become one of the largest online crowdfunding platforms in China. By the end of May 2016, there are 16,846 projects in total which have selected Zhongchou.cn to raise funds. About 887,923 funders participate in funds pledge, and more than 180 million RMB has been pledged. It provides a platform for companies to post and promote their projects, and to interact with funders or potential funders. Users on the platforms can pledge a project, "like" a project, and post comments about a project.

Our major focus is the degree of project success rather than the possibility of success, thus we only collect data from those projects that have already succeeded. We collected projects in Zhongchou.cn before Feb 2014. To ensure the sample include only successful projects, we selected projects which completed over $100 \%$ that is an indicator for success. There were 1513 successful projects. The collected data was cleansed before being processed as per the requirements of our study.

\subsection{Measures}

The degree of project success. It is defined as the total amount of funds a project can obtain after it is already successful (after reaching its initial funding goal). However, projects differ in the volume of funds that they ask for, it is inappropriate to directly operationalize the degree of project success as the total amount funds. This study operationalizes it as the percentage of reaching the funding goal of a project, which is the ratio of the received funds and target funding goal (as shown in the formula below). We use its $\log$ transformation because of its skewness.

DegreeofProjectSuccess $_{\mathrm{i}}=\ln \left(\frac{\text { ReceivedFunding }_{\mathrm{i}}}{\text { CrowdfundingGoal }_{\mathrm{i}}}\right)$

Funds pledge. The platform enables the crowds to pledge in projects based on their preferences. Users can choose the amount they plan to pledge in a particular crowdfunding project. In this study, the crowds' behavior of funds pledge is operationalized as the total number of funders in a particular project.

Popularity Creation. InZhongchou.com, the crowds can give "like" to a project if they perceive the project as a good or attractive one. Therefore, the crowds' behavior of popularity creation is operationalized as the total number of "like" a project receives.

On-site communication. The crowds can give comments to a certain project if they are interested in. In turn, fundraiser can respond to the comments to interact with the crowds. Since fundraisers' responses are direct under the comments they want to respond, we thus operationalize the crowds' behavior of on-site communication as the total number of comments a project has received.

Crowdfunding Goal. Each project has a target goal that it wants to achieve. Therefore, the crowdfunding goal is operationalized as the total amount a project seeks to raise.

Max Pledge and Min Pledge. The projects will set the reward scheme which includes different levels of backing price. By selecting a level of backing and funding on it, the crowds can obtain corresponding rewards. Max pledge and Min pledge are operationalized as the maximum backing price and the minimum backing price in the reward scheme, respectively.

Non-profit pledge. In addition to fund with expectation of rewards, many projects offer an option to fund without any profit or returns through pledging a small amount of money (such as RMB1). The funders who only have little interests in the projects but want to help the project initiators would like to choose this option. We operationalized the crowds' behavior of non-profit pledge as the total number of pledgers who select to pledge this option in a particular project. 


\begin{tabular}{|l|c|c|c|c|}
\hline \multicolumn{5}{|c|}{ Table 2 Descriptive Statistics } \\
\hline Variables & Min & Max & Mean & $\begin{array}{c}\text { Std. } \\
\text { Deviation }\end{array}$ \\
\hline $\begin{array}{l}\text { Ln(projectsucces } \\
\text { s) }\end{array}$ & 0.0 & 8.76 & 4.94 & 0.56 \\
\hline $\begin{array}{l}\text { On-site } \\
\text { communication }\end{array}$ & 1 & 1746 & 38.34 & 107.22 \\
\hline Funds pledge & 0 & 39561 & 107.34 & 1042.71 \\
\hline $\begin{array}{l}\text { Crowdfunding } \\
\text { Goal }\end{array}$ & 100 & 520000 & 32592.59 & 204802.02 \\
\hline Popularity & 0 & 7408 & 216.75 & 512.23 \\
\hline Non-profit & 0 & 17 & 0.12 & 0.90 \\
pledge & 1.0 & 200000 & 9930.71 & 65276.88 \\
\hline Max Pledge & 0.0 & 44999 & 182.73 & 1433.04 \\
\hline
\end{tabular}

\section{Data Analysis and Results}

We used an ordinary least square (OLS) method to analyze our data by using SPSS. We performed panel data random effects regression with robust standard error and pooled over ordinary least square analysis with standard error clustered by user. Clustered standard errors can control for potential heteroscedasticity. To test the inverse U-shaped effect of crowd participation in funds pledge, we included the quadratic term of funds pledge into the regression formula-fundspledge ${ }^{2}$. The regression formula is presented below:

DegreeofProjectSuccess $=\beta_{0}+\beta_{1} *$ Fundspledge ${ }^{2}+\beta_{2} *$ Fundspledge $+\beta_{3} *$ Communication $+\beta_{4} *$ Popularity $+\beta_{5} *$ FundingGoal $+\beta_{6} *$ NonProfitPledge $+\beta_{7} *$ Maxpledge $+\beta_{8} *$ Minpledge

Where Fundspledge $e^{2}$ refers to the square of number of funds pledge, Fundspledge refers to the number of funds pledge, Communication refers to the total number of comments, FundingGoal refers to the total amount of a project target, Maxpledge refers to the maximum backing price in a project's reward scheme, Minpledge refers to the minimum backing price in a project's reward scheme, and NonProfitPledge refers to the total number of pledgers who don't expect any rewards.

In this study, crowdfunding goal, Maxpledge, Minpledge, and NonProfitPledge were included as control variables, which represented the crowd capability of fundraisers. Before conducting data analysis, Koenker statistic was used to check heteroscedasticity. The Koenker results $\left(x^{2}=10.873\right.$ with $\mathrm{p}=0.209$ ) indicated that heteroscedasticity is not exist in this study.

\begin{tabular}{|l|l|l|l|l|}
\hline \multicolumn{3}{|c}{ Table 3. Results of the Regression Analysis } \\
\hline \multirow{2}{*}{ Parameter } & $\beta$ & $\begin{array}{l}\text { Std. } \\
\text { Error }\end{array}$ & \multicolumn{2}{l|}{$\begin{array}{l}\text { Hypothesis } \\
\text { Test }\end{array}$} \\
\cline { 3 - 5 } & & & df & Sig. \\
\hline Funds pledge2 & -0.416 & 0.000 & 1 & 0.007 \\
\hline Funds pledge & 0.473 & 0.000 & 1 & 0.000 \\
\hline Popularity & -0.028 & 0.000 & 1 & 0.219 \\
\hline $\begin{array}{l}\text { On-site } \\
\text { communication }\end{array}$ & 0.310 & 0.000 & 1 & 0.000 \\
\hline $\begin{array}{l}\text { Crowdfunding } \\
\text { Goal }\end{array}$ & -0.174 & 0.000 & 1 & 0.000 \\
\hline Maxpledge & 0.012 & 0.000 & 1 & 0.618 \\
\hline Minpledge & 0.012 & 0.000 & 1 & 0.636 \\
\hline Nonprofitpledge & 0.014 & 0.015 & 1 & 0.575 \\
\hline \multicolumn{2}{|l|}{ R Square $=0.117(\mathrm{df}=8)$} & & & \\
\hline
\end{tabular}

The results of the regression analysis are summarized in Table 3. The results indicated that crowd participation in funds pledge had an inverse U-shaped effect on the degree of project success with significant coefficients on both quadratic term of funds pledge $(\beta=$ $-0.416, \mathrm{p}<0.01)$ and funds pledge $(\beta=0.473, \mathrm{p}<0.001)$, supporting $\mathrm{H} 1$. The results also suggested that on-site communication had a significant positive effect $(\beta=$ $0.310, \mathrm{p}<0.001)$ on the degree of project success. Thus, $\mathrm{H} 3$ is also supported. Surprisingly, our results indicated that popularity creation did not exhibit any significant effect $(\beta=-0.028, p>0.05)$ on the degree of project success, not supporting $\mathrm{H} 2$. Overall, crowd participation in funds pledge and on-site communication explained $11.7 \%$ of the variance in the degree of project success.

A summary of hypotheses results are shown in Table 4 that $\mathrm{H} 1$ and $\mathrm{H} 3$ are supported and $\mathrm{H} 2$ is not supported.

\begin{tabular}{|l|l|l|}
\hline \multicolumn{3}{|c|}{ Table 4 Summary of Hypotheses } \\
\hline Hypothesis & Variables & Support \\
\hline $\begin{array}{l}\text { H1 The crowds' participations } \\
\text { in funds pledge has an inverse }\end{array}$ & $\begin{array}{l}\text { Fundpledge } \\
2\end{array}$ & Supported \\
$\begin{array}{l}\text { U-shaped relationship with the } \\
\text { degree of project success. }\end{array}$ & Fundpledge & \\
\hline $\begin{array}{l}\text { H2 The crowds' participations } \\
\text { in popularity creation is } \\
\text { positively related to the degree } \\
\text { of project success. }\end{array}$ & Popularity & $\begin{array}{l}\text { Not } \\
\text { supported }\end{array}$ \\
\hline $\begin{array}{l}\text { H3 The crowds' participations } \\
\text { in on-site communication is } \\
\text { positively related to the degree } \\
\text { of project success. }\end{array}$ & $\begin{array}{l}\text { On-site } \\
\text { communicat } \\
\text { ion }\end{array}$ & Supported \\
\hline
\end{tabular}




\section{Discussion and Conclusion}

\subsection{Key Findings}

This study aims to explore the antecedents of the degree of project success through the perspective of capital-giving agents - the crowds. Drawing upon the theory of crowd capital, we constructed the degree of project success as a key crowd capital sought by fundraisers in the crowdfunding context, and indicated the critical role of the crowds. We then focused on the crowd participation through which the crowds can exert effects on crowd capital generation (i.e., to raise more funds). Three ways of crowd participation were identified, namely funds pledge, popularity creation, and on-site communication.

First, our empirical results indicated that the crowd participation in funds pledge had an inverse U-shaped relationship with the degree of project success. Funds pledge is the major way to generate crowd capitalraising more funds. Previous literature revealed mixed findings that some studies indicated that funds pledge occurred by herding, i.e., following others' pledge behaviors, implying that a project with high degree of success would attract more funders [17, 30]; while others found the opposite results [16]. Our work reconciles this inconsistency of prior studies on funders' participation in reward-based crowdfunding platforms, and finds out that there should be a tipping point.

Second, in addition to funds pledge, the crowds can also participate through some on-site social functions. Our results for on-site social functions indicated that onsite communication was found to have positive influence on the degree of project success. This is consistent with prior literature of crowdfunding that higher frequency of communication between project fundraisers and funders leads to larger volume of funds generated [32] even the projects have already reached the set funding goal. This finding is consistent with the effect of communication on other types of successes, such as new product development $[7,12]$.

Surprisingly, the hypothesized effect of popularity creation on the degree of project success was not supported. This may be explained by the fact that crowdfunding platforms are different from other conventional social media platforms [9]. Hence, even many people click 'like' on the projects, they may not support projects by pledging funds so that they do not substantially contribute to the degree of project success. This result could also support the recent decision of crowdfunding platforms in withdrawing the "like" button.

\subsection{Limitations and Future Research}

This study also has limitations. First, unlike prior crowdfunding studies that collect data from famous platforms, such as Kickstarter, we tested our hypotheses by crawling data from a reward-based crowdfunding platform in China. It gives us some new insights but may constrain the generalizability of our results. Therefore, future studies should replicate this study to other crowdfunding contexts to ascertain our findings.

Second, we only investigated the direct effects of the three ways of crowd participation on the degree of project success. In future studies, other types of effects should be considered. For example, popularity creation and on-site communication may attract potential funders and encourage them to pledge funds. Hence, these two types of crowd participation may predict funds pledge or exert effects on the degree of project success through the mediation effect of funds pledge. Further, the possible interdependencies among these three types of crowd participation could be investigated, and some conditional factors could also be explored.

Third, we operationalized crowd participation as a count variable; that is, we utilized the number of individuals to represent the crowd participation behavior. This operationalization is intuitive but ignores some meaningful information. For instance, the specific amount of funds that is pledged by each funder could also be used to represent funds pledge behavior. Furthermore, the number of comments was taken to represent on-site communication; while the quality of the comments, including the specific content and valence, and the interaction dynamic between the crowd and the fundraisers could also be used to represent onsite communication. Future studies should employ these aspects of crowd participation into consideration to gain a more comprehensive understand crowd participation behaviors.

\subsection{Implications}

This study has several theoretical and practical implications. First, this research contributes to the literature of crowdfunding project success by studying the degree of project success instead of the possibility to succeed. Prior literature mainly takes the success as a binary construct that distinguishes between success and not success [3, 19, 32, 34, 35]. However, every fundraiser expects to raise as much funds as possible even the original funding goal has been reached, because new business ventures can be more smoothly started up with more funds. Furthermore, a project with high degree of success is also critical in influencing both the success of other projects and the entire crowdfunding platform [18]. By exploring the determinants of the degree of project success, we could add new understanding to the extant literature of project 
success to develop further knowledge of projects that are already successful and expect to pursue more success.

Second, our work also contributes to the literature of crowdfunding project success by drawing upon the theory of crowd capital and examining the phenomenon from the perspective of the crowds. As indicated in prior literature, crowdfunding is a two-sided market which interlinks capital-seeking agents (i.e., fundraisers) and an IT-mediated crowd of capital-giving agents (i.e., backers or funders) [13]. The existing project success literature mainly explored the antecedents of project success through the perspective of fundraisers $[3,19,32$, $34,35]$. However, the theory of crowd capital proposes that the crowd capital-the resources (i.e., funds in the current context) generated from an IT-mediated crowd-depends on both capital capability of the fundraisers, as well-studied in prior literature, and the resource possessed by the crowds that has received less attention in the literature [22-25, 27]. Our study takes an early attempt in this direction, and enriches the existing understanding of project success.

Third, our work advances the understanding of funds pledge on the degree of project success. Although the crowd participation in funds pledge is expected to generate crowd capital, i.e., to raise more funds in the current context, the findings in the existing studies remain inconsistent and mixed. Specifically, On one hand, some studies indicate that funds pledge is driven by herding others' behaviors $[17,30]$. That is, a project with high degree of success attracts more funders. On the other hand, some other studies provide opposite results that a crowding-out effect may occur in some situations [16]. That is, a project with low degree of success could attract relatively more funders. Our work argues for an inverse-U relationship between funds pledge and the degree of project success. In doing so, we could reconcile the inconsistency and offer a relatively new insight on the relationship between funds pledge and the degree of project success.

Forth, our work also provides guidance to practitioners. The initial objective of fundraisers is to achieve their set funding goals. After that, the fundraisers expect to raise more funds. Our study could set a light to fundraisers about how a project with high degree of success generate crowd capital from ITmediated crowds in the reward-based and All-orNothing crowdfunding platforms. As our empirical results show, there is a tipping point between funds pledge and the degree of project success. This tipping point indicates that the large amount of funders cannot guarantee high degree of project success. Instead, they should maximize the total funding amount within a moderate number of funders. Despite of funds pledge, the fundraisers should increase communications with the funders, i.e., improve interactions with the crowd, which in turn will have positive effect on the degree of project success.

In conclusion, the current study draws upon the theory of crowd capital and focuses on the effect of the crowds, crowd participation in particular, on the degree of project success. Three ways of crowd participationfunds pledge, popularity creation, and on-site communication - are identified and examined. The former one is argued to have an inverse-U relationship with the degree of project success; while the latter two are expected to directly increase the degree of project success. The empirical data validate most of our argumentations. Our work enriches the literature of crowdfunding on the project success and set a light for future research.

\section{References}

[1] A.K. Agrawal, C. Catalini, A. Goldfarb, The geography of crowdfunding, in, (National Bureau of Economic Research, 2011).

[2] J. Andreoni, Impure altruism and donations to public goods: a theory of warm-glow giving, The economic journal, (1990) 464-477.

[3] M. Beier, K. Wagner, Crowdfunding between Social Media and E-Commerce: Online Communication, Online Relationships and Fundraising Success on Crowdfunding Platforms, in: Discussion Papers on Economics and Entrepreneurial Management 03/2014, (2014).

[4] W.M. Bukowski, B. Hoza, Popularity and friendship: Issues in theory, measurement, and outcome, in: Peer relationships in child development, (New York: John Wiley \& Sons, Inc, 1989), pp. 15-45.

[5] E. Burkett, Crowdfunding Exemption-Online Investment Crowdfunding and US Secrutiies Regulation, A, Transactions: Tenn. J. Bus. L., 13(2011) 63.

[6] G. Burtch, A. Ghose, S. Wattal, An empirical examination of the antecedents and consequences of contribution patterns in crowd-funded markets, Information Systems Research, 24(3) (2013) 499-519.

[7] N.E. Coviello, R.M. Joseph, Creating major innovations with customers: insights from small and young technology firms, Journal of Marketing, 76(6) (2012) 87-104.

[8] K. De Buysere, O. Gajda, R. Kleverlaan, D. Marom, M. Klaes, A framework for European crowdfunding, in: European Crowdfunding Network (ECN), available at www. europecrowdfunding.

crowdfunding_framework, (2012).

[9] R.P. Fisk, L. Patrício, A. Ordanini, L. Miceli, M. Pizzetti, A. Parasuraman, Crowd-funding: transforming customers into investors through innovative service platforms, Journal of Service Management, 22(4) (2011) 443-470.

[10] E.M. Gerber, J.S. Hui, P.-Y. Kuo, Crowdfunding: Why people are motivated to post and fund projects on crowdfunding platforms, in: Proceedings of the International Workshop on Design, Influence, and Social Technologies: Techniques, Impacts and Ethics, (2012). 
[11] G. Giudici, M. Guerini, C. Rossi Lamastra, Why crowdfunding projects can succeed: the role of proponents' individual and territorial social capital, in: Available at SSRN 2255944, (2013)

[12] K.E. Gruner, C. Homburg, Does customer interaction enhance new product success?, Journal of business research, 49(1) (2000) 1-14.

[13] P. Haas, I. Blohm, J.M. Leimeister, An Empirical Taxonomy of Crowdfunding Intermediaries, in: ICIS Proceedings, (2014).

[14] Y. Inbar, O. Barzilay, Community Impact on Crowdfunding Performance, in: Available at SSRN 2524910 , (2014).

[15] A.K. Korman, Task success, task popularity, and selfesteem as influences on task liking, Journal of Applied Psychology, 52(6) (1968) 484-490.

[16] V. Kuppuswamy, B.L. Bayus, Crowdfunding creative ideas: The dynamics of project backers in Kickstarter, UNC Kenan-Flagler Research Paper, 2013-15(2014).

[17] Z. Li, J.A. Duan, Dynamic Strategies for Successful Online Crowdfunding, in: Available at SSRN 2506352, (2014).

[18] J. Liu, L. Yang, Z. Wang, J. Hahn, Winner takes all? The "blockbuster effect" in crowdfunding platforms, in: Thirty Sixth International Conference on Information Systems, (Fort Worth, 2015).

[19] Y. Liu, P. Bhattacharya, Z. Jiang, Video-Evoked Perspective Taking on CrowdFunding Platforms: Impacts on Contribution Behavior, in: ICIS Proceedings, (2014).

[20] A. Moisseyev, Effect of social media on crowdfunding project results, in: Colledge of Business Administration, (University of Nebraska-Lincoln, 2013).

[21] E. Mollick, The dynamics of crowdfunding: An exploratory study, Journal of Business Venturing, 29(1) (2014) $1-16$.

[22] J. Prpić, P. Shukla, The Theory of Crowd Capital, in: HICSS, (Hawaii, 2013).

[23] J. Prpić, P. Shukla, The contours of crowd capability, in: 47th Hawaii International Conference on System Science, (Hawaii, 2014).

[24] J. Prpić, P. Shukla, Crowd capital in governance contexts, Prpić, J., \& Shukla, P.(2014). Crowd Capital in Governance Contexts. Oxford Internet Institute, University of Oxford-IPP, (2014).

[25] J. Prpić, P. Shukla, Crowd Science: Measurements, Models, and Methods, in: HICSS, (2016).
[26] J. Prpić, P. Shukla, Y. Roth, J.-F. Lemoine, Is the world flat? Unpacking the geography of crowd capital, in: Open and User Innovation Conference, (2014).

[27] J. Prpic', P.P. Shukla, J.H. Kietzmann, I.P. McCarthy, How to work a crowd: Developing crowd apital through crowdsourcing, Business Horizons, 58(2015) 77-85.

[28] A. Schwienbacher, B. Larralde, Crowdfunding of small entrepreneurial ventures, in: Handbook of Entrepreneurial Finance, (Oxford University Press, 2010).

[29] S. Smith, F. Windmeijer, E. Wright, The effect of social information on charitable donations: Evidence from the (running) field1, in, (University of Bristol Working Paper, http://www. bristol. ac. uk/cmpo/events/2012/charitablegiving/smith. pdf (accessed on May 1, 2014), 2012).

[30] F. Thies, M. Wessel, The Circular Effects of Popularity Information and Electronic Word-of-Mouth on Consumer Decision-Making: Evidence from a Crowdfunding Platform, in: ECIS proceedings, (2014).

[31] C. Ward, V. Ramachandran, Crowdfunding the next hit: Microfunding online experience goods, in: Workshop on Computational Social Science and the Wisdom of Crowds at NIPS2010, (2010).

[32] S. Xiao, X. Tan, M. Dong, J. Qi, How to Design Your Project in the Online Crowdfunding Market? Evidence from Kickstarter, in: ICIS Proceedings, (2014).

[33] J. Zhang, P. Liu, Rational herding in microloan markets, Management science, 58(5) (2012) 892-912.

[34] N. Zhang, S. Datta, K.N. Kannan, An Analysis of Incentive Structures in Collaborative Economy: An Application to Crowdfunding Platform, in: Available at SSRN 2518662, (2014).

[35] H. Zheng, D. Li, J. Wu, Y. Xu, The role of multidimensional social capital in crowdfunding: A comparative study in China and US, Information \& Management, 51(4) (2014) 488-496.

[36] H. Zheng, N. Wan, D. Chen, T. Wang, Antecedents of Project Implementation Success in Crowdfunding, in: PACIS2014, (2014), pp. 1-13.

[37] J. Zywica, J. Danowski, The faces of Facebookers: Investigating social enhancement and social compensation hypotheses; predicting Facebook ${ }^{\mathrm{TM}}$ and offline popularity from sociability and self - esteem, and mapping the meanings of popularity with semantic networks, Journal of Computer Mediated Communication, 14(1) (2008) 1-34. 